\title{
The Elevated Rate of Cesarean Section and Its Contribution to Non-Communicable Chronic Diseases in Latin America: The Growing Involvement of the Microbiota
}

\section{OPEN ACCESS}

Edited by:

Richard Eugene Frye, Arkansas Children's Hospital Research Institute, United States

Reviewed by: Consolato Sergi,

University of Alberta, Canada Brian Godman, Karolinska Institute (KI), Sweden Christoph Bührer,

Charité Universitätsmedizin Berlin, Germany

*Correspondence: Fabien Magne fabienmagne@med.uchile.cl; Martin Gotteland mgottela@med.uchile.cl

Specialty section:

This article was submitted to Child Health and

Human Development, a section of the journal

Frontiers in Pediatrics

Received: 23 May 2017 Accepted: 18 August 2017 Published: 04 September 2017

Citation:

Magne F, Puchi Silva A, Carvajal B and Gotteland M (2017) The Elevated

Rate of Cesarean Section and Its Contribution to Non-Communicable Chronic

Diseases in Latin America: The Growing Involvement of the Microbiota.

Front. Pediatr. 5:192. doi: 10.3389/fped.2017.00192

\section{Fabien Magne ${ }^{1 *}$, Alexa Puchi Silva ${ }^{2}$, Bielka Carvajal $^{3}$ and Martin Gotteland ${ }^{4,5 *}$}

${ }^{1}$ Microbiology and Mycology Program, Institute of Biomedical Sciences (ICBM), Faculty of Medicine, University of Chile, Santiago, Chile, ${ }^{2}$ Faculty of Medicine, Andres Bello University, Vina del Mar, Santiago, Chile, ${ }^{3}$ Department of Women and Newborn's Health Promotion, University of Chile, Santiago, Chile, ${ }^{4}$ Department of Nutrition, Faculty of Medicine, University of Chile, Santiago, Chile, ${ }^{5}$ Institute of Nutrition and Food Technology (INTA), University of Chile, Santiago, Chile

The current recommendation of the World Health Organization (WHO) regarding cesarean section (C-section) is that this clinical practice should be carried out only under specific conditions, when the health or life of the mother/newborn dyad is threatened, and that its use should not exceed $10-15 \%$ of the total deliveries. However, over the last few decades, the frequency of C-section delivery in medium- and high-income countries has rapidly increased worldwide. This review describes the evolution of this procedure in Latin American countries, showing that today more than half of newborns in the region are delivered by $\mathrm{C}$-section. Given that $\mathrm{C}$-section delivery is more expensive than vaginal delivery, its use has increased more rapidly in the private than the public sector; nevertheless, the prevalence of $\mathrm{C}$-section deliveries in the public sector is higher than the WHO's recommendations and continues to increase, representing a growing challenge for Latin America. Although the medium- and long-term consequences of C-section delivery, as opposed to vaginal delivery, on the infant health are unclear, epidemiological studies suggest that it is associated with higher risk of developing asthma, food allergy, type 1 diabetes, and obesity during infancy. These findings are important, as the incidence of these diseases in the Latin American pediatric population is also increasing, particularly obesity. Although the link between these diseases and delivery mode remains controversial, recent studies indicate that the establishment of the gut microbiota is delayed in infants born by $\mathrm{C}$-section during the postnatal period, i.e., during a critical developmental window for the maturation of the newborn's immune system. This delay may favor the subsequent development of inflammatory and metabolic disorders during infancy. Accordingly, from a public health perspective, it is important to slow down and eventually reverse the pattern of increased C-section use in the affected populations.

Keywords: cesarean section, gut microbiota, childhood diseases, Latin America, metabolic diseases, chronic immune disorders 


\section{INTRODUCTION}

For a long time, maternal mortality associated with pregnancy, birth, and puerperal complications has represented a significant public health problem. One of the strategies aimed at improving mother and newborn outcomes and decreasing mortality in this period is delivery by cesarean section (C-section). This procedure is mainly indicated in the case of placenta praevia, when the fetus is not adequately positioned for birth, when the mother has uncontrolled high blood pressure or diabetes, or in case of multiple pregnancies. However, C-section is not without risk for the mother/infant dyad, and a cautious medical evaluation is required to determine whether the benefits exceed the risks and justify its use (1). A 14-year follow-up of more than two million Canadian women showed that those with low-risk pregnancies undergoing their first C-section were three times more likely to die or suffer serious complications, including infections, blood clots, and heart attack, compared with these who delivered vaginally (2). An additional concern is that mothers who undergo C-section surgery need more time to recover than those who give birth vaginally. Similarly, newborns delivered by C-section have a higher risk of suffering respiratory distress and are less likely to be breastfed than those born vaginally (3). The pioneering studies of Lagercrantz have shown that many of the newborn's health benefits of vaginal delivery are related to the surge of plasma cortisol and catecholamines that occurs during passage through the birth canal. This hormonal increase positively impacts postnatal glycemia levels, blood pressure, alveolar liquid absorption, and body temperature, and also contributes to neurological adaptation. In contrast, this hormone surge, as well as changes in the physiological parameters previously described, is clearly attenuated in infants born through scheduled C-section (4). In addition to acute negative effects on the newborn, C-section is currently emerging as a risk factor for the development of metabolic and immune diseases, whose incidence is rapidly increasing worldwide. Considering these and other antecedents, the World Health Organization (WHO) currently estimates that C-sections should not exceed $15 \%$ of all deliveries (5).

This review describes the rapid increase of this procedure in Latin America and the growing health challenge that it represents for these countries, taking in consideration its frequent association with increased risk of metabolic and immune disorders in the infancy, and the fact that most of these disorders are currently growing in this continent. Finally, we also emphasize the microbiota as a factor that could eventually explain the relationship between $\mathrm{C}$-section and metabolic and immune diseases.

The search of scientific literature was performed using Medline and the Scielo bibliographic databases. Scielo (Scientific Electronic Library Online) is a digital library mainly grouping scientific publications from Latin American countries. We selected studies describing $\mathrm{C}$-section rates in different countries including from Latin America and the impact of C-section on immune and metabolic diseases. Combinations of the following key words were used: " cesarean section," "C-section," "Vaginal Delivery," " Latin America," "South America," "infant health," "Type-1 diabetes," "Celiac disease," "Allergic diseases," "asthma," "Obesity," "metabolic diseases," "Type-2 diabetes," "chronic immune disorders," "mucosal immune system," "bacterial gut colonization," "early gut colonization," "vaginal seeding," "prebiotics," "probiotics," "microbiome," and/or "microbiota." Search was carried out for the articles published during the 1995-2017 period. Full-text articles were downloaded and reviewed to identify those representing the intended context, and data were subsequently extracted from the relevant publications.

\section{THE UNCONTROLLED INCREASE OF C-SECTION IN LATIN AMERICA}

Despite WHO recommendations, the prevalence of C-section has been increasing worldwide over the last decades, from $6.7 \%$ in 1990 to $19.1 \%$ in 2014; this increase has been more drastic in middle- and high-income countries than in developing areas (6). A study reported that C-section rate was less than $10 \%$ in $54 / 137$ countries, between 10 and $15 \%$ in 14 countries and surpassed $15 \%$ in 69 countries (7). In the countries with low C-section rates, several factors played a role in keeping these rates low: its higher financial cost, a lack of adequate surgical infrastructure (in rural areas), and misconceptions/lack of information which cause women who are in true need of C-section reluctant to accept the procedure (8). In countries with rates greater than $15 \%, 6.2$ million unnecessary C-sections were performed in 2008, representing a global cost of USD $\$ 2.32$ billion. While increased use of C-section deliveries has improved rates of maternal and newborn mortality in low-income countries, there are few data in middle- and high-income countries, confirming that the majority of C-sections performed in these countries are unjustified $(9,10)$.

Currently, South America is the region with the highest C-section rate (42.9\%), followed by North America (32.3\%), Oceania (31.1\%), Europe (25\%), and Asia (19.2\%) (6). This is not a new trend as in the 1990s, Latin American and the Caribbean countries already had the world's highest C-section rate (about 23\%). This tendency has accelerated in recent years, as South America was the region that saw the largest increase in $\mathrm{C}$-section deliveries from 1990 to 2014 (19.4\%). A correlation between country's per capita gross domestic product and C-section rates has been reported for 18 Latin American countries (6). The C-section rate in Uruguay, Chile, Brazil, and Colombia, which together represents more than $40 \%$ of births in the region, has increased significantly during the last decade (Table 1). Peru has the lowest C-section rate in the region ( 30\%); however, it has also seen the greatest increase in recent years. Brazil is the country with the highest C-section rate in the world, reaching $40-45 \%$ in the

TABLE 1 | Changes in C-section rates in Latin American countries.

\begin{tabular}{lcccccc}
\hline Country & Year & Rate (\%) & Year & Rate (\%) & Increase (\%) & Reference \\
\hline Peru & 2000 & 13.0 & 2014 & 28.6 & 120 & $(15,16)$ \\
Uruguay & 2000 & 23.9 & 2015 & 43.1 & 80 & a \\
Chile & 1986 & 27.7 & 2015 & 44.7 & 61 & $(17,18)$ \\
Brazil & 1998 & 39.2 & 2013 & 56.7 & 45 & $(19,20)$ \\
Colombia & 1998 & 24.9 & 2013 & 45.7 & 84 & $(21)$ \\
Argentina & $1995-2000$ & 25.4 & 2011 & 29.1 & 15 & $(22)$
\end{tabular}

${ }^{a}$ Ministerio de Salud de la República Oriental de Uruguay. Estadísticas Vitales. Available from: http://www.msp.gub.uy/EstVitales/ 
public and $80-95 \%$ in the private sector, with high variability according the region/city $(11,12)$. Interestingly, this country is also ranked among the top 10 with the highest number of preterm births worldwide (13) and some researchers have suggested a link between C-section rate and the rise in premature births (14).

Unfortunately, it may be considered that C-sections have become as a part of the "modern" maternal lifestyle, a cultural norm, and a marker of economic status in the Latin American countries. This is supported by the fact that the rate of cesarean delivery is twofold higher in Latin American women living in Europe than in the native women (23-25). Although this phenomenon might be explained by linguistic barriers, a recent study showed that the $\mathrm{C}$-section rate in immigrant Brazilian women living in Portugal (and sharing the same language) was about $48 \%$, compared with $35.4 \%$ in the Portuguese women. This suggests that cultural background is an important factor determining the selection of the mode of delivery (26). C-section without medical indication is being preferred by a growing number of pregnant women, due to the erroneous perception that it is safer for both the mother and newborn (27), the bad experience of previous delivery, the fear of vaginal delivery and labor-associated pain, and the successfully lobbying of clinics or medical staff. Indeed, for them, C-section is more convenient due to the frequent lack of available hospital beds and because it is plannable and economically more interesting (28-30). However, it is noteworthy that childbirth medicalization can leave women with the feeling that they are no longer active participants in the birth process. In some cases, this may eventually result in disrespectful, abusive or coercive situations affecting mother's rights (31). This is particularly illustrated by a recent article published by the Daily Telegraph reporting the case of a woman with two previous $\mathrm{C}$-sections, who left the hospital after the doctors denied her a vaginal delivery, and who was subsequently arrested and forced to have her baby by cesarean. Accordingly, it is clear that more emphasis should be placed on initiatives such as the "Maternal and Friendly Delivery Initiative" issued from the Coalition for Improving Maternity Services whose mission is, among others, to promote a full range of options for pregnancy, childbirth and baby feeding, respecting the decisions of mothers (32). Based on these antecedents and with the aim to slow down this "C-section epidemic," the Brazilian government recently passed a law requiring pregnant women to sign an informed consent form acknowledging the risks of C-section before going into surgery. Simultaneously, it also launched a partnership with several hospitals to promote vaginal birth. A preliminary evaluation suggests a $76 \%$ increase in vaginal births, as well as a reduction in C-section associated complications in those hospitals involved in this initiative. However, it is clear that more time is necessary to evaluate the real impact of this new regulation on $\mathrm{C}$-section rate in Brazil.

\section{C-SECTIONS AS A POSSIBLE RISK FACTOR FOR INFANT HEALTH}

Experimental data have linked labor avoidance to altered stress responses, immune function, and epigenetic processes in offspring (33-36). A number of epidemiological studies have also been conducted, to determine the eventual impact of birth by $\mathrm{C}$-section on health risks during infancy; here, we summarize these findings.

\section{Type 1 Diabetes (T1D)}

A meta-analysis of 9,939 cases of T1D showed that C-section was associated with a higher risk of this childhood disease (OR: 1.19 [1.04-1.36]) after adjusting for gestational age, birth weight, maternal age, birth order, breastfeeding, and maternal diabetes (37). In an Australian study examining perinatal risk factors for T1D in children under 6 years of age, planned C-section was again shown to increase the risk of T1D (OR: 1.30 [1.01-1.69]) compared to vaginal delivery (38). Similarly, in a Scottish study of more than 320,000 children, the risk of T1D was also higher (adjusted OR: 1.35 [1.05-1.75]) in those delivered by planned $\mathrm{C}$-section than in those born by unscheduled C-section. These children also had higher risk of death (all-causes) prior to 21 years of age (adjusted OR: 1.41 [1.05-1.90]) compared with vaginally born children (39). In contrast, a retrospective study in Denmark looked at the effect of C-section vs. vaginal delivery on chronic immune diseases in all children born from 1973 to 2012, using the Danish national registries. About 1.9 million children were studied and a significantly increased risk of asthma, systemic connective tissue disorders, juvenile arthritis, inflammatory bowel diseases, immune deficiency, and leukemia was observed in those born through C-section; however, they did not find any increased risk of celiac disease, psoriasis, or T1D (40). Similar observations were reported by Clausen et al., also in Denmark (41).

\section{Celiac Disease}

Studies have also suggested an association between C-section and the risk of celiac disease. In a population-based, casecontrol study of 11,749 Swedish children with biopsy-verified celiac disease and 53,887 age- and sex-matched controls, planned, but not emergency, C-section was associated with an increased risk of later celiac disease (adjusted OR: 1.15 [1.04-1.26]), compared with vaginally delivered children (42). Similarly, a retrospective study using the Danish national registries that included all children born in Denmark between 1997 and 2012 showed that those delivered by unscheduled C-section had an increased risk of ulcerative colitis (adjusted OR: 1.47 [1.02-2.12]) and celiac disease (adjusted OR: 1.52 [1.06-2.20]), whereas children delivered by elective $\mathrm{C}$-section had an increased risk of lower respiratory tract infections and juvenile idiopathic arthritis. The effect of elective C-section was greater than the effect of acute C-section on asthma risk (43).

\section{Allergic Diseases and Asthma}

On the other hand, Bager et al. conducted a meta-analysis of 26 studies (23 cohort and 3 case-control studies) including approximately 1.3 million children, concluding that those born by C-section had higher risk of allergic rhinitis (OR: 1.23 [1.12-1.35]), food allergy or atopy (OR: 1.32 [1.12-1.55]), and asthma (OR: 1.18 [1.05-1.32]) (44). In a study by Black et al., children born by $\mathrm{C}$-section were also more prone to develop asthma requiring hospitalization and to use salbutamol at 5 years of age (adjusted OR: 1.22 [1.11-1.35] and 1.13 [1.01-1.26], 
respectively), as compared to vaginally delivered children (39). Similar observations have been reported in other studies and meta-analyses (45). Data from 459 children born and cared for in the same maternity ward and followed for 3 years showed that C-section was a significant and independent predictor of food allergy (OR: 3.15 [1.14-8.70]) but not atopic dermatitis (46), confirming the conclusions of a recent systematic review (47). In a retrospective study of more than 7,500,000 Danish children, Kristensen and Henriksen also reported a higher risk of asthma in children born by both unscheduled and elective C-section $(\mathrm{OR}=1.06$ [1.02-1.10] and 1.24 [1.20-1.28], respectively) (43).

\section{Obesity}

Researchers have also examined the impact of C-section on the subsequent development of obesity. In a Chinese study of 181,380 children, C-section was associated with a higher risk of being overweight after multivariate adjustment [in particular for prepregnancy maternal body mass index (BMI)] (OR: 1.13 [1.08-1.18]) (48). A small, multivariate analysis of 917 American children ( 12 years of age) indicated that those born by C-section had approximately twice the likelihood of being obese (OR: 1.87 [1.19-2.95]) or overweight (OR: 1.86 [1.27-2.73]) than those who were born vaginally; this differed by gender, with males at greater risk (49). Recent systematic reviews and meta-analyses have drawn similar conclusions: Li et al. reported an increased risk of overweight/obesity in children (OR: 1.32 [1.15-1.51]), adolescents (OR: 1.24 [1.00-1.54]) and adults (OR: 1.50 [1.02-2.20]) born by C-section, and Kuhle et al. showed an increased risk of obesity after adjustment for maternal BMI (OR: 1.29 [1.16-1.44]) $(50,51)$. Analysis of mothers who had multiple births found that infants born by vaginal birth following a previous $\mathrm{C}$-section were $31 \%$ less likely to become obese than infants born by a repeated $\mathrm{C}$-section delivery. Moreover, within-family analysis showed that individuals born through C-section delivery were 64\% more likely to be obese than their siblings born through vaginal delivery. The adjusted risk ratio for obesity among offspring delivered via $\mathrm{C}$-section vs. those delivered vaginally was 1.15 [1.06-1.26] $(p=0.002)$. This association between delivery mode and obesity was stronger for children who were born by C-section among women without indications for cesarean delivery (52). These results, therefore, suggest that $\mathrm{C}$-section affects obesity risk, independently of lifestyle and genetic factors.

Collectively, these results indicate that C-section is associated with increased risk of both metabolic diseases and chronic immune disorders during infancy.

\section{THE GROWING INCIDENCE OF METABOLIC DISEASES AND CHRONIC IMMUNE DISORDERS IN LATIN AMERICA}

The rapidly increasing frequency of C-section in Latin America is, therefore, an important public health risk that must be considered by both medical professional and public policy makers, as this procedure constitutes a significant risk factor for diseases that are also gradually growing in the region. Latin America has a population of approximately 600 million individuals and is characterized by high ethnic diversity and genetic heterogeneity, due to its Amerindian heritage. Here, we outline recent changes in the incidence of metabolic diseases and chronic immune disorders in Latin America.

\section{Type 1 Diabetes}

Epidemiological data on T1D in Latin America are scarce (53). Higher rates of T1D are observed in countries with higher incomes, increased urbanization, and low Amerindian heritage. For example, a study of children under 14 years of age in Chile reported a lower incidence of T1D in the native aboriginal Mapuche population than in the Caucasian population ( 0.42 vs. 1.58 per 100,$000 ; p<0.001)(54,55)$. Furthermore, a significant increase in the incidence of T1D was observed in the Chilean population from 2000 to 2004 (5.4 vs. 8.33 per 100,000; $p<0.04$ ). Similarly, in Mexico a substantial increase (from 3.4 to 6.2 per $100,000)$ in the incidence of T1D was reported in children under 19 years of age from 2000 to 2010 (56). These studies indicate that the incidence of T1D has increased recently in Latin America.

\section{Allergic Diseases and Asthma}

Data from the International Study of Asthma and Allergies in Childhood showed that the prevalence of asthma or allergic disease ranged from 18 to $27 \%$ in Brazil, Uruguay, Paraguay, and Peru; these percentages are similar to those reported in developed countries, which are most affected by this disease (such as Western Europe) (57). However, these incidence rates are growing $(+0.32 \% /$ year $)$, and are accompanied by mortality rates (primarily due to bronchial asthma) that reach 5.6 per 100,000 in some countries, such as Mexico and Uruguay (57). Asthma is more frequent in urban, low-income populations, mainly due to the accelerated pace of urbanization and migration, the adoption of a westernized lifestyle, and environmental changes (increasing exposure to allergens and indoor/outdoor pollutants). Similar trends have been reported in regards to the incidence of food allergies in Latin America $(58,59)$.

\section{Obesity}

The prevalence of obesity has increased significantly in Latin America, with about $57 \%$ of the adult population classified as overweight and $19 \%$ as obese $(60,61)$. The highest rates of childhood obesity are currently found in Chile (23\% in 6-year-olds), and the lowest in Peru $(1.8 \%$ in children $<5$ years of age) $(62,63)$. In Mexico, increased incidence of overweight/obesity has particularly affected adolescent girls and women, with an annual increase of about 1.5\% from 1988 to 2012; however, incidence rates have increased much slower for preschoolers $(0.3 \%$ per year; 1988 2012) and men (0.7\% per year; 2000-2012) (64). In Colombia, from year 2005 to 2010, the proportion of individuals classified as overweight increased from 13.9 to $17.5 \%$ in children aged 5 to 17 years of age (62). In Brazil, the prevalence of obesity in children and adolescents has risen $240 \%$ in the past two decades (65); a similar increase has been observed in Chilean children (66).

While increased C-section rates in Latin America are not solely responsible for the increasing incidence of asthma, food allergies, obesity and T1D in the region, it is nevertheless a contributing factor. Accordingly, decreasing the number of 
unnecessary C-section surgeries could eventually attenuate the burden of these diseases.

\section{WHY DOES C-SECTION FAVOR THE DEVELOPMENT OF METABOLIC DISEASES AND CHRONIC IMMUNE DISORDERS DURING INFANCY?}

\section{C-Section Alters the Postnatal Establishment of Gut Microbiota in the Newborn}

C-section influences the establishment of gut microbiota in the newborns, thus affecting their exposure to bacterial antigens. Bacterial transmission from mother to newborn is currently considered a crucial factor for the establishment of the gut microbiota, which in turn shapes host immune responses (67). In fact, intestinal bacteria are involved in the development of gut-associated lymphoid tissues (GALT), the induction of oral tolerance, and (in rabbits) the diversification of the pre-immune antibody repertoire. In addition, animal studies have shown that an altered (by antimicrobials) gut microbiota early in life affects host physiology, through increased bodyweight and adiposity (68-70). Interestingly, these effects were more pronounced if this alteration occurred prior to weaning, suggesting the presence of a critical period during which an altered gut microbiota can impact the host's health (68).

It is generally accepted that the fetus grows and develops in a sterile environment within the uterus, and that its passage through the birth canal during delivery is the baby's first exposure to microorganisms. The pioneering bacterial communities that colonize the intestine originate primarily from the maternal vaginal and fecal microbiota in the case of vaginal delivery and from the mother's skin microbiota in the case of C-section delivery. In the case of vaginal delivery, this community is primarily composed of facultative anaerobic bacteria, including Enterococcus, Staphylococcus, and enterobacteria, which consume the oxygen present in the intestinal lumen, assisting in the creation of an anaerobic environment that strictly anaerobic bacteria can colonize. Accordingly, at the end of the infant's first week of life, the gut microbiota of a breastfed newborn is dominated by Bifidobacterium sp., with lower counts of Bacteroides sp., Clostridium sp., and lactic acid bacteria. The emergence of this Bifidobacterium-dominated microbiota is favored by the significant quantity of oligosaccharides (10-12 g/L) and other bifidogenic compounds (nucleotides, casein-derived glycomacropeptide) contained in breast milk $(71,72)$. The diversity of the infant gut microbiota increases gradually when solid foods are introduced, eventually reaching a stable adult-like microbiota at 2-3 years of age (73). Various factors influence the gut's colonization, such as the use of and type of formula, as well as genetic, environmental, and lifestyle factors (73-75).

C-section alters bacterial colonization due to the fact that the fetus has no direct contact with the maternal vaginal/fecal microbiota during delivery, and as antimicrobials are frequently administered during surgery (76). Dominguez-Bello et al. observed that the bacterial composition of meconium samples from vaginally delivered newborns was similar to that of the vaginal microbiota of their mother; in contrast, meconium from newborns delivered by $\mathrm{C}$-section was most similar to the maternal skin microbiota (dominantly composed of Streptococcus spp., Staphylococcus spp., and Propionibacterium spp.) (77). In addition, delivery mode has also been shown to influence the bacterial composition of breast milk, which is another important early bacterial source $(78,79)$. C-section delivery delays gut colonization by Bifidobacterium, Lactobacillus, and perhaps most importantly Bacteroides spp. Establishment of these bacteria is thus delayed, and typically mirrors that of a vaginally born infant only at around 6 months of age (80); however, some studies report that residual dysbiosis may persist for longer, until 2 or even 7 years of age (Table 2) $(81,82$ ).

Although many studies have reported gut dysbiosis in patients with asthma, allergies, obesity or T1D (87), few studies have examined alterations in the postnatal microbiota of infants that go on to develop one of these pathologies, and those that exist mostly focus on allergies (Table 3). Various microorganisms that colonize the infant gut early in life, such as Bifidobacterium (88-91), Lactobacillus (90, 91), Enterobacteriaceae, and Clostridium (92), have been associated with the subsequent development of allergies. Although no specific microorganism has been clearly identified as either protective or inductive, various studies point to Clostridium difficile as favoring allergy development. In fact, colonization of the gut by this opportunistic pathogen is accompanied by disruption to the microbiota prior to the onset of allergic disease. As previously stated, various studies have described lower microbial diversity in children who subsequently developed allergies. One study showed that atopic eczema was preceded by decreased microbial diversity, specifically affecting the genus Bacteroides (93). It is possible that a more diverse gut microbiota is more efficient in improving the maturation of the immune system and reducing the risk of chronic immune disorders (94).

A longitudinal study analyzing the gut microbiota of infants from birth to 7 years of age, showed that those who became overweight at 7 years harbored significantly fewer Bifidobacterium sp. at 6 and 12 months of age compared with children who were normal weight at 7 years of age (101). More longitudinal studies evaluating the development of the early gut microbiota and its impact on the development of obesity, T1D, and food allergy are necessary to confirm whether alterations in the microbiota's composition and/or a delay in the colonization process precedes the development of these diseases.

\section{Postnatal Gut Dysbiosis Affects the Maturation of the Infant's Mucosal Immune System}

Decreased levels of intestinal Bacteroides spp. associated with C-section delivery are significant, as this microorganism strongly influences host physiology and metabolism. Studies in germ-free mice indicate that Bacteroides thetaiotaomicron participates in maintaining gut barrier function by increasing epithelial expression of the small proline-rich protein $2 \mathrm{~A}$, a polymeric immunoglobulin receptor, and matrilysin, a matrix metalloproteinase 
TABLE 2 | Long-term alteration of the gut microbiota associated with cesarean section.

\begin{tabular}{|c|c|c|c|c|c|c|}
\hline Country & Age & Effective & Method & $\begin{array}{l}\text { Bacterial diversity } \\
\text { difference }\end{array}$ & Microbial changes & Reference \\
\hline Finland & 6 months & $\begin{array}{l}C D=30 \\
V D=34\end{array}$ & Culture & ND & $\begin{array}{l}\text { The colonization rate of Lactobacillus-like bacteria was lower } \\
\text { in the CD group than in the VD group } \\
\text { In the CD group, the colonization rate of the Bacteroides fragilis } \\
\text { group was only half that of infants in the VD group ( } 36 \text { vs. } 76 \% \text { ) }\end{array}$ & (80) \\
\hline India & 3 months & $\begin{array}{l}C D=10 \\
V D=73\end{array}$ & qPCR & ND & $\begin{array}{l}\text { The Bacteroides-Prevotella group was more abundant in the feces } \\
\text { of VD infants compared with those of CD from birth up to three months }\end{array}$ & (83) \\
\hline Korea & 6 months & $\begin{array}{l}C D=3 \\
V D=3\end{array}$ & $\begin{array}{l}16 \mathrm{~S} \text { rDNA } \\
\text { pyrosequencing }\end{array}$ & No & $\begin{array}{l}\text { The Clostridium genus increased with age in the infants in our study } \\
\text { born by CD, while consistently lower levels were observed in infants } \\
\text { born by VD during the first } 6 \text { months of life }\end{array}$ & (84) \\
\hline USA & 6 weeks & $\begin{array}{l}C D=12 \\
V D=11\end{array}$ & $\begin{array}{l}16 \mathrm{~S} \text { rDNA } \\
\text { pyrosequencing } \\
\text { Metagenomic }\end{array}$ & ND & $\begin{array}{l}\text { Bacteroidetes were more abundant through } 6 \text { weeks of age in stool } \\
\text { of VD infants. Infant fecal microbiota in both delivery groups did not } \\
\text { resemble maternal rectal or vaginal microbiota. Differences in fecal } \\
\text { bacterial gene between CS and VD at } 6 \text { weeks clustered in metabolic } \\
\text { pathways and were mediated by the abundance of Proteobacteria } \\
\text { and Bacteroidetes }\end{array}$ & (85) \\
\hline Sweden & 24 months & $\begin{array}{l}C D=9 \\
V D=15\end{array}$ & $\begin{array}{l}16 \mathrm{~S} \text { rDNA } \\
\text { pyrosequencing }\end{array}$ & $\begin{array}{l}\text { Infants born through } \\
\text { CS had lower total } \\
\text { microbiota diversity }\end{array}$ & $\begin{array}{l}\text { Infants born by CS had a lower abundance and diversity of the } \\
\text { Bacteroidetes phylum and were less often colonized with the } \\
\text { Bacteroidetes phylum }\end{array}$ & (82) \\
\hline Canada & 4 months & $\begin{array}{l}C D=6 \\
V D=18\end{array}$ & $\begin{array}{l}16 \mathrm{~S} \text { rDNA } \\
\text { pyrosequencing }\end{array}$ & $\begin{array}{l}\text { Infants born by } \\
\text { elective CS had the } \\
\text { lowest richness and } \\
\text { diversity }\end{array}$ & $\begin{array}{l}\text { Escherichia-Shigella and Bacteroides species were underrepresented } \\
\text { in infants born by CD. Infants born by elective CD had particularly low } \\
\text { bacterial richness and diversity }\end{array}$ & (86) \\
\hline Finland & 7 years & $\begin{array}{l}C D=31 \\
V D=29\end{array}$ & $\begin{array}{l}\text { Fluorescent in situ } \\
\text { hybridization method }\end{array}$ & ND & $\begin{array}{l}\text { Compared with infant born by CD, higher numbers of clostridia were } \\
\text { found in children born by VD }\end{array}$ & (81) \\
\hline
\end{tabular}

$C D$, cesarean delivery; $V D$, vaginal delivery; $N D$, not determined.

involved in defensin activation in Paneth cells $(102,103)$. The combination of Bacteroides fragilis and Bacillus subtilis consistently promoted GALT maturation in the rabbit appendix and led to the development of the pre-immune antibody repertoire, as reflected by increased somatic diversification of VDJ-C $\mu$ genes in appendix B cells (104). Bacteroides species have also been implicated in the improvement of gut immunity and inflammatory response, by stimulating the plasmocyte production of secretory IgA (105). A polysaccharide A-expressing strain of B. fragilis also suppressed the release of the pro-inflammatory cytokine IL-17 in the intestine (106). Interestingly, adult mice born by C-section showed a lower proportion of Foxp $3^{+}$regulatory T cells and tolerogenic $\mathrm{CD}_{103^{+}}$dendritic cells, along with lower IL-10 expression in mesenteric lymph nodes and the spleen, suggesting negative long-term systemic effects of C-section delivery on the immune system of these animals (107).

Collectively, these results suggest that high levels of Bacteroides sp. (and eventually Bifidobacterium) present in the infant gut during the first 6 months following vaginal delivery exert health-promoting effects by favoring the maturation of GALT, mucosal immunity and oral tolerance, and reducing the risk of immune and metabolic disorders during infancy. On the contrary, for infants born by C-section delivery, the absence (or low abundance) of these microorganisms during this important physiological window of development appears to result in disturbances of immune homeostasis and a higher risk of developing metabolic and immune disorders later in life.

\section{INTERVENTIONS THAT MAY IMPROVE GUT COLONIZATION IN INFANTS BORN BY C-SECTION}

With the aim of introducing the appropriate maternal microbiota to an infant delivered via C-section, and to decrease the risk of immune and metabolic disorders, Dominguez-Bello et al. carried out a study in which they immediately swabbed newborns after delivery with a gauze previously set in the maternal vagina for $1 \mathrm{~h}$ prior to surgery (108). The gut bacterial community of these newborns was enriched in vaginal bacteria during the first 30 days of their life, similar to vaginally delivered children; in children born by $\mathrm{C}$-section who were not swabbed, these bacterial populations were underrepresented. Although the long-term health consequences of restoring the microbiota of infants delivered by $\mathrm{C}$-section remain unclear, these results demonstrate that vaginal microbes can be partially restored at birth in C-section-delivered babies (108). One argument against such "vaginal seeding" is the potential presence of pathogens in the maternal vaginal microbiota to be introduced to the newborn.

Another approach proposed to assist in the "normal" colonization of the gut microbiota in infants born by $\mathrm{C}$-section has been the administration of probiotics. Garcia Rodenas et al. observed that the administration formula containing $L$. reuteri DSM17938 did not affect the microbiota of vaginally delivered infants, but promoted fast recovery from gut dysbiosis induced by C-section delivery (109). 
TABLE 3 | Diseases associated with gut microbiota alterations in early life.

\begin{tabular}{|c|c|c|c|c|c|c|c|c|}
\hline Disease & Country & $\begin{array}{l}\text { Age of } \\
\text { diagnosed } \\
\text { disease } \\
\text { (years) }\end{array}$ & $\begin{array}{c}\text { Effective } n \\
\text { (control group) }\end{array}$ & $\begin{array}{l}\text { Early bacterial } \\
\text { diversity }\end{array}$ & Early gut microbiota data & $\begin{array}{l}\text { Age of microbiome } \\
\text { analysis }\end{array}$ & Method & Reference \\
\hline Allergy & Sweden & 5 years & $n=13(n=25)$ & ND & $\begin{array}{l}\downarrow \text { Prevalence of lactobacilli group I (L. rhamnosus, L. casei, } \\
\text { and L. paracasel) at the first week } \\
\downarrow \text { Prevalence of Bifidobacterium adolescents at the first week. } \\
\downarrow \text { Prevalence of Clostridium difficile during first } 2 \text { months. }\end{array}$ & $\begin{array}{l}1 \text { week } \\
1 \text { month } \\
2 \text { months }\end{array}$ & qPCR & (90) \\
\hline $\begin{array}{l}\text { Allergy (against } \\
\text { food and inhalant } \\
\text { allergens) }\end{array}$ & Sweden & 5 years & $n=16(n=19)$ & ND & $\begin{array}{l}\downarrow \text { Lactobacilli prevalence at first weeks of life } \\
\downarrow \text { Bifidobacterium bifidum prevalence at } 1 \text { week of age }\end{array}$ & $\begin{array}{l}1 \text { week } \\
2 \text { weeks } \\
1 \text { month } \\
2 \text { months } \\
12 \text { months }\end{array}$ & qPCR & (91) \\
\hline $\begin{array}{l}\text { Allergy (atopic } \\
\text { dermatitis and } \\
\text { allergic rhinitis/ } \\
\text { rhinoconjunctivitis) }\end{array}$ & $\begin{array}{l}\text { Estonia } \\
\text { Sweden }\end{array}$ & 2 years & $n=18(n=26)$ & ND & $\begin{array}{l}\uparrow \text { Clostridia prevalence at } 3 \text { months } \\
\downarrow \text { Bacteroides prevalence at } 12 \text { months }\end{array}$ & $\begin{array}{l}1 \text { week } \\
1 \text { month } \\
3 \text { months } \\
6 \text { months } \\
12 \text { months }\end{array}$ & Culture methods & (88) \\
\hline Asthma & Sweden & 7 years & $n=8(n=39)$ & $\downarrow$ Total bacteria & NS & $\begin{array}{l}1 \text { week } \\
1 \text { month }\end{array}$ & $\begin{array}{l}16 \mathrm{~S} \text { rDNA } \\
\text { pyrosequencing }\end{array}$ & (95) \\
\hline Asthma & Netherlands & $6-7$ years & $n=99(n=832)$ & ND & $\uparrow$ C. difficile prevalence & 1 month & qPCR & (96) \\
\hline Atopic eczema & Sweden & 2 years & $n=20(n=20)$ & $\begin{array}{l}\downarrow \text { Total bacteria } \\
\downarrow \text { Phylum Bacteroidetes } \\
\downarrow \text { Genus Bacteroides }\end{array}$ & NS & 1 month & $\begin{array}{l}16 \mathrm{~S} \text { rDNA } \\
\text { pyrosequencing }\end{array}$ & (93) \\
\hline Atopic eczema & $\begin{array}{l}\text { Sweden } \\
\text { Great Britain } \\
\text { Italy }\end{array}$ & 18 months & $n=15(n=20)$ & $\downarrow$ Total bacteria & ND & 1 week & $\begin{array}{l}\text { T-RFLP } \\
\text { TTGE }\end{array}$ & (97) \\
\hline Atopic sensitization & Finland & 12 months & $n=12(n=17)$ & ND & $\begin{array}{l}\uparrow \text { Clostridia concentration } \\
\downarrow \text { Bifidobacterium concentration }\end{array}$ & 3 weeks & $\mathrm{FISH}$ & (89) \\
\hline Eczema & US & 6 months & $n=9(n=12)$ & $\downarrow$ Total bacteria & ND & $\begin{array}{l}1 \text { month } \\
4 \text { months }\end{array}$ & DGGE & (98) \\
\hline Eczema & Australia & 12 months & $n=33(n=65)$ & $\downarrow$ Total bacteria & ND & 1 week & T-RFLP & (99) \\
\hline Eczema & Singapore & 2 years & $n=28(n=32)$ & ND & $\begin{array}{l}\uparrow \text { Enterobacteriaceae abundance } \\
\uparrow \text { Clostridium perfringens abundance }\end{array}$ & $\begin{array}{l}3 \text { days } \\
1 \text { month } \\
3 \text { months } \\
1 \text { year }\end{array}$ & FISH-FC & (92) \\
\hline Eczema & Singapore & 5 years & $n=15(n=19)$ & ND & $\downarrow$ Bifidobacterium abundance & $\begin{array}{l}3 \text { days } \\
1 \text { month } \\
3 \text { months } \\
1 \text { year }\end{array}$ & FISH-FC & (92) \\
\hline
\end{tabular}




\section{CONCLUSION}

The prevalence of $\mathrm{C}$-section is increasing worldwide, despite WHO recommendations to the contrary, being this increase most acute in Latin America. This phenomenon may be due to several factors, such as: low maternal self-efficacy; a fear of childbirth, which is related to the social construction of this event; fear of labor pain; and a predisposition by the medical team to perform the surgery (110-112). It is therefore important to implement public health programs focused on reversing this trend, being $\mathrm{C}$-section is now considered as a significant risk factor for a several number of immune and metabolic diseases, whose incidences are currently growing worldwide. To reduce unnecessary C-sections and encourage vaginal birth, various strategies should be considered, such as the implementation of standardized protocols, request of a second medical opinion prior to surgery, improving maternal empowerment during pregnancy and delivery, maternal and medical collaboration on birth plans, alternatives to endure labor pain, creation of pleasurable labor environments, allowing the presence of a companion during birth, and midwife-led care during pregnancy and labor $(23,113,114)$. Furthermore, as breastfeeding also plays a key role in the establishment of the early gut microbiota following birth, the following strategies should also be considered: adequate support by trained midwifes/lactation experts, public health campaigns supporting/encouraging breastfeeding, restriction on formula hand-out at maternities, and the fact that infants stay in their mother's hospital room overnight rather than in a separate nursery.

The negative impacts of $\mathrm{C}$-section on later health may be due to the delay in the postnatal establishment of the gut microbiota and subsequent alterations to the maturation of the mucosal immune system. Accordingly, the infant gut microbiota may be a potential target for preventing or attenuating the disorders associated with C-section delivery. However, most studies on the infant gut microbiota and its health impacts cited in this review have been conducted in developed countries. This is a significant bias on our understanding of these phenomena, as the microbiota is highly variable between individuals according their dietary habits, lifestyle, and genetic background (75). Longitudinal studies are therefore necessary to increase our knowledge on the impact of C-section delivery on the development of the gut microbiota during infancy and the incidence of chronic immune and metabolic disorders in developing countries, including Latin America.

\section{AUTHOR CONTRIBUTIONS}

All authors participated equally in the writing of this review. $\mathrm{BC}$ performed the literature review of $\mathrm{C}$-section rates in Latin America. APS performed the literature review of metabolic and immune diseases in Latin America. FM and MG conceived of the idea, the review, and edited this work.

\section{ACKNOWLEDGMENTS}

The authors thank Anne Lagomarcino for editing the language in this manuscript. 


\section{REFERENCES}

1. Belizán JM, Althabe F, Cafferata ML. Health consequences of the increasing caesarean section rates. Epidemiology (2007) 18:485-6. doi:10.1097/EDE. 0b013e318068646a

2. Liu S, Liston RM, Joseph KS, Heaman M, Sauve R, Kramer MS, et al. Maternal mortality and severe morbidity associated with low-risk planned cesarean delivery versus planned vaginal delivery at term. Can Med Assoc J (2007) 176:455-60. doi:10.1503/cmaj.060870

3. O'Shea TM, Klebanoff MA, Signore C. Delivery after previous cesarean: longterm outcomes in the child. Semin Perinatol (2010) 34:281-92. doi:10.1053/j. semperi.2010.03.008

4. Lagercrantz H. The good stress of being born. Acta Paediatr (2016) 105:1413-6. doi:10.1111/apa.13615

5. World Health Organization. WHO Statement on Caesarean Section Rates. World Health Organization (2016). Available from: http://www.who.int/ reproductivehealth/publications/maternal_perinatal_health/cs-statement/en/

6. Betrán AP, Ye J, Moller A-B, Zhang J, Gülmezoglu AM, Torloni MR, et al. The increasing trend in caesarean section rates: global, regional and national estimates: 1990-2014. PLoS One (2016) 11:e0148343. doi:10.1371/journal. pone. 0148343

7. Gibbons L, Belizán JM, Lauer JA, Betrán AP, Merialdi M, Althabe F. The global numbers and costs of additionally needed and unnecessary caesarean sections performed per year: overuse as a barrier to universal coverage. Background Paper, 30 Health Systems Financing. World Health Report (2010). Available from: http://www.who.int/healthsystems/topics/financing/healthreport/30C-sectioncosts.pdf

8. Ishaq R, Baloch NS, Iqbal Q, Saleem F, Hassali MA, Iqbal J, et al. Frequency and evaluation of the perceptions towards caesarean section among pregnant women attending public hospitals in Pakistan and the implications. Hosp Pract (2017) 45:104-10. doi:10.1080/21548331.2017.1328250

9. Althabe F, Sosa C, Belizán JM, Gibbons L, Jacquerioz F, Bergel E. Cesarean section rates and maternal and neonatal mortality in low-, medium-, and highincome countries: an ecological study. Birth (2006) 33:270-7. doi:10.1111/ j.1523-536X.2006.00118.x

10. Betrán AP, Merialdi M, Lauer JA, Bing-Shun W, Thomas J, Van Look P, et al. Rates of caesarean section: analysis of global, regional and national estimates. Paediatr Perinat Epidemiol (2007) 21:98-113. doi:10.1111/j.1365-3016. 2007.00786.x

11. Ribeiro VS, Figueiredo FP, Silva AAM, Bettiol H, Batista RFL, Coimbra LC, et al. Why are the rates of cesarean section in Brazil higher in more developed cities than in less developed ones? Braz J Med Biol Res (2007) 40:1211-20. doi:10.1590/S0100-879X2006005000130

12. Barros FC, Matijasevich A, Maranhão AGK, Escalante JJ, Rabello Neto DL, Fernandes RM, et al. Cesarean sections in Brazil: will they ever stop increasing? Rev Panam Salud Publica (2015) 38:217-25.

13. WHO. The Global Action Report on Preterm Birth Born Too Soon. (2012). Available from: http://www.who.int/pmnch/media/news/2012/201204_borntoosoon-report.pdf

14. do Carmo Leal M, Esteves-Pereira AP, Nakamura-Pereira M, Torres JA, Theme-Filha M, Domingues RMSM, et al. Prevalence and risk factors related to preterm birth in Brazil. Reprod Health (2016) 13:127. doi:10.1186/ s12978-016-0230-0

15. Instituto Nacional de Estadística e Informática. Encuesta Demográfica y de Salud Familiar-ENDES. (2014). 490 p. Available from: https://www.inei. gob.pe/media/MenuRecursivo/publicaciones_digitales/Est/Lib1211/pdf/ Libro.pdf

16. Instituto Nacional de Estadísticas e Informática - Peru. Peru - Encuesta Demográfica y de Salud Familiar. (2014). 235 p. Available from: https://www. inei.gob.pe/media/MenuRecursivo/publicaciones_digitales/Est/Lib1211/pdf/ Libro.pdf

17. Murray SF, Serani Pradenas F. Cesarean birth trends in Chile, 1986 to 1994. Birth (1997) 24(4):258-63.

18. OECD. Health at a Glance 2015: OECD Indicators. Paris: OECD Publishing (2015). 220 p. doi:10.1787/health_glance-2015-en

19. Ministério da Saúde Brazil. Proporção de partos cesáreos. (2000). Available from: http://tabnet.datasus.gov.br/cgi/tabcgi.exe?idb2000/f08.def

20. Ministério da Saúde Brazil. Proporção de partos cesáreos. (2013). Available from: http://tabnet.datasus.gov.br/tabdata/LivroIDB/2edrev/f08.pdf
21. Rubio-Romero JA, Fonseca-Pérez JE, Molina S, Buitrago-Leal M, Zuleta JJ, Ángel-Müller E. Racionalización del uso de la cesárea en Colombia. Consenso de la Federación Colombiana de Obstetricia y Ginecología (FECOLSOG) y la Federación Colombiana de Perinatología (FECOPEN). Bogotá, 2014. Rev Colomb Obstet Ginecol (2014) 65:139-51. doi:10.18597/rcog.62

22. Belizán JM, Althabe F, Barros FC, Alexander S. Rates and implications of caesarean sections in Latin America: ecological study. BMJ (1999) 319:1397-400.

23. Størksen HT, Garthus-Niegel S, Adams SS, Vangen S, Eberhard-Gran M. Fear of childbirth and elective caesarean section: a population-based study. BMC Pregnancy Childbirth (2015) 15:221. doi:10.1186/s12884-015-0655-4

24. Merten S, Wyss C, Ackermann-Liebrich U. Caesarean sections and breastfeeding initiation among migrants in Switzerland. Int J Public Health (2007) 52:210-22. doi:10.1007/s00038-007-6035-8

25. Vangen S, Stoltenberg C, Skrondal A, Magnus P, Stray-Pedersen B. Cesarean section among immigrants in Norway. Acta Obstet Gynecol Scand (2000) 79:553-8. doi:10.1080/j.1600-0412.2000.079007553.x

26. Teixeira C, Correia S, Victora CG, Barros H. The Brazilian preference: cesarean delivery among immigrants in Portugal. PLoS One (2013) 8:e60168. doi:10.1371/journal.pone.0060168

27. Hannah ME. Planned elective cesarean section: a reasonable choice for some women? CMAJ (2004) 170:813-4. doi:10.1503/cmaj.1032002

28. Arcia A. US nulliparas' perceptions of roles and of the birth experience as predictors of their delivery preferences. Midwifery (2013) 29:885-94. doi:10.1016/j.midw.2012.10.002

29. Stoll K, Hall W, Janssen P, Carty E. Why are young Canadians afraid of birth? A survey study of childbirth fear and birth preferences among Canadian University students. Midwifery (2014) 30:220-6. doi:10.1016/j. midw.2013.07.017

30. Wang E. Requests for cesarean deliveries: the politics of labor pain and pain relief in Shanghai, China. Soc Sci Med (2017) 173:1-8. doi:10.1016/j. socscimed.2016.11.032

31. Miller S, Lalonde A. The global epidemic of abuse and disrespect during childbirth: history, evidence, interventions, and FIGO's mother-baby friendly birthing facilities initiative. Int J Gynaecol Obstet (2015) 131:S49-52. doi:10.1016/j.ijgo.2015.02.005

32. Hotelling BA. The coalition for improving maternity services: evidence basis for the ten steps of mother-friendly care. J Perinat Educ (2007) 16:38-43. doi:10.1624/105812407X197744

33. Ronca AE, Abel RA, Ronan PJ, Renner KJ, Alberts JR. Effects of labor contractions on catecholamine release and breathing frequency in newborn rats. Behav Neurosci (2006) 120:1308-14. doi:10.1037/0735-7044.120.6.1308

34. Salminen S, Gibson GR, McCartney AL, Isolauri E. Influence of mode of delivery on gut microbiota composition in seven year old children. Gut (2004) 53:1388-9. doi:10.1136/gut.2004.041640

35. Round JL, Mazmanian SK. The gut microbiota shapes intestinal immune responses during health and disease. Nat Rev Immunol (2009) 9:313-23. doi:10.1038/nri2515

36. Schlinzig T, Johansson S, Gunnar A, Ekström T, Norman M. Epigenetic modulation at birth - altered DNA-methylation in white blood cells after caesarean section. Acta Paediatr (2009) 98:1096-9. doi:10.1111/j.1651-2227. 2009.01371.x

37. Cardwell CR, Stene LC, Joner G, Cinek O, Svensson J, Goldacre MJ, et al. Caesarean section is associated with an increased risk of childhood-onset type 1 diabetes mellitus: a meta-analysis of observational studies. Diabetologia (2008) 51:726-35. doi:10.1007/s00125-008-0941-z

38. Algert CS, McElduff A, Morris JM, Roberts CL. Perinatal risk factors for early onset of type 1 diabetes in a 2000-2005 birth cohort. Diabet Med (2009) 26:1193-7. doi:10.1111/j.1464-5491.2009.02878.x

39. Black M, Bhattacharya S, Philip S, Norman JE, McLernon DJ. Planned cesarean delivery at term and adverse outcomes in childhood health. JAMA (2015) 314:2271-9. doi:10.1001/jama.2015.16176

40. Sevelsted A, Stokholm J, Bønnelykke K, Bisgaard H. Cesarean section and chronic immune disorders. Pediatrics (2015) 135:e92-8. doi:10.1542/ peds.2014-0596

41. Clausen TD, Bergholt T, Eriksson F, Rasmussen S, Keiding N, Løkkegaard EC. Prelabor cesarean section and risk of childhood type 1 diabetes. Epidemiology (2016) 27:547-55. doi:10.1097/EDE.0000000000000488

42. Mårild K, Stephansson O, Montgomery S, Murray JA, Ludvigsson JF. Pregnancy outcome and risk of celiac disease in offspring: a nationwide case-control 
study. Gastroenterology (2012) 142:39-45.e3. doi:10.1053/j.gastro.2011. 09.047

43. Kristensen K, Henriksen L. Cesarean section and disease associated with immune function. J Allergy ClinImmunol (2016) 137:587-90. doi:10.1016/j. jaci.2015.07.040

44. Bager P, Wohlfahrt J, Westergaard T. Caesarean delivery and risk of atopy and allergic disease: meta-analyses. Clin Exp Allergy (2008) 38:634-42. doi:10.1111/j.1365-2222.2008.02939.x

45. Thavagnanam S, Fleming J, Bromley A, Shields MD, Cardwell CR. A metaanalysis of the association between caesarean section and childhood asthma. Clin Exp Allergy (2008) 38:629-33. doi:10.1111/j.1365-2222.2007. 02780.x

46. Papathoma E, Triga M, Fouzas S, Dimitriou G. Cesarean section delivery and development of food allergy and atopic dermatitis in early childhood. Pediatr Allergy Immunol (2016) 27:419-24. doi:10.1111/pai.12552

47. Marrs T, Bruce KD, Logan K, Rivett DW, Perkin MR, Lack G, et al. Is there an association between microbial exposure and food allergy? A systematic review. Pediatr Allergy Immunol (2013) 24:311-20.e8. doi:10.1111/ pai. 12064

48. Li H, Ye R, Pei L, Ren A, Zheng X, Liu J. Caesarean delivery, caesarean delivery on maternal request and childhood overweight: a Chinese birth cohort study of 181380 children. Pediatr Obes (2014) 9:10-6. doi:10.1111/j. 2047-6310.2013.00151.x

49. Wang L, Alamian A, Southerland J, Wang K, Anderson J, Stevens M. Cesarean section and the risk of overweight in grade 6 children. Eur J Pediatr (2013) 172:1341-7. doi:10.1007/s00431-013-2043-2

50. Kuhle S, Tong OS, Woolcott CG. Association between caesarean section and childhood obesity: a systematic review and meta-analysis. Obes Rev (2015) 16:295-303. doi:10.1111/obr.12267

51. Li H, Zhou Y, Liu J. The impact of cesarean section on offspring overweight and obesity: a systematic review and meta-analysis. Int J Obes (2013) 37:893-9. doi:10.1038/ijo.2012.195

52. Yuan C, Gaskins AJ, Blaine AI, Zhang C, Gillman MW, Missmer SA, et al. Association between cesarean birth and risk of obesity in offspring in childhood, adolescence, and early adulthood. JAMA Pediatr (2016) 170:e162385. doi:10.1001/jamapediatrics.2016.2385

53. Gómez-Díaz RA, Garibay-Nieto N, Wacher-Rodarte N, Aguilar-Salinas CA. Epidemiology of type 1 diabetes in Latin America. Curr Diabetes Rev (2014) 10:75-85. doi:10.2174/1573399810666140223183936

54. Carrasco E, Pérez-Bravo F, Dorman J, Mondragón A, Santos JL. Increasing incidence of type 1 diabetes in population from Santiago of Chile: trends in a period of 18 years (1986-2003). Diabetes Metab Res Rev (2006) 22:34-7. doi:10.1002/dmrr.558

55. Larenas G, Montecinos A, Manosalva M, Barthou M, Vidal T. Incidence of insulin-dependent diabetes mellitus in the IX region of Chile: ethnic differences. Diabetes Res Clin Pract (1996) 34(Suppl):S147-51. doi:10.1016/ S0168-8227(96)90022-4

56. Gomez-Diaz RA, Perez-Perez G, Hernandez-Cuesta IT, del Carmen RodríguezGarcía J, Guerrero-Lopez R, Aguilar-Salinas CA, et al. Incidence of type 1 diabetes in Mexico: data from an institutional register 2000-2010. Diabetes Care (2012) 35:e77-77. doi:10.2337/dc12-0844

57. Pitrez PM, Stein RT. Asthma in Latin America: the dawn of a new epidemic. Curr Opin Allergy Clin Immunol (2008) 8:378-83. doi:10.1097/ACI. 0b013e32830fb911

58. Prescott SL, Pawankar R, Allen KJ, Campbell DE, Sinn JK, Fiocchi A, et al. A global survey of changing patterns of food allergy burden in children. World Allergy Organ J (2013) 6:21. doi:10.1186/1939-4551-6-21

59. Sánchez J, Sánchez A. Epidemiology of food allergy in Latin America. Allergol Immunopathol (2015) 43:185-95. doi:10.1016/j.aller.2013.07.001

60. World Health Organization. Obesity and Overweight. (2014). Available from: http://www.who.int/mediacentre/factsheets/fs311/en/

61. Rivera JÁ, de Cossío TG, Pedraza LS, Aburto TC, Sánchez TG, Martorell R. Childhood and adolescent overweight and obesity in Latin America: a systematic review. Lancet Diabetes Endocrinol (2014) 2:321-32. doi:10.1016/ S2213-8587(13)70173-6

62. Kain J, Orellana Y, Leyton B, Taibo M, Vio F. Association between socioeconomic vulnerability and height with obesity in low-income Chilean children in the transition from preschool to first grade. Ecol Food Nutr (2014) 53:241-55. doi:10.1080/03670244.2013.813848
63. Informe Mapa Nutricional. (2015). Available from: https://www.junaeb.cl/ wp-content/uploads/2016/11/Informe-Mapa-Nutricional-2015-final.pdf

64. Barquera S, Campos-Nonato I, Hernández-Barrera L, Pedroza A, RiveraDommarco JA. [Prevalence of obesity in Mexican adults 2000-2012]. Salud Publica Mex (2013) 55(Suppl 2):S151-60. doi:10.21149/spm.v55s2.5111

65. Eduardo Reis CG, Aragão Vasconcelos IL, Farias de Barros JN. Políticas públicas de nutrição para o controle da obesidade infantil Policies on nutrition for controlling childhood obesity. Rev Paul Pediatr (2011) 29:625-33. doi:10.1590/S0103-05822011000400024

66. Kain J, Corvalán C, Lera L, Galván M, Uauy R. Accelerated growth in early life and obesity in preschool Chilean children. Obesity (2009) 17:1603-8. doi:10.1038/oby.2009.37

67. Endo A, Tang MLK, Salminen S. 1.8 gut microbiota in infants. World Rev Nutr Diet (2015) 113:87-91. doi:10.1159/000360322

68. Cho I, Yamanishi S, Cox L, Methé BA, Zavadil J, Li K, et al. Antibiotics in early life alter the murine colonic microbiome and adiposity. Nature (2012) 488:621-6. doi:10.1038/nature11400

69. Cox LM, Yamanishi S, Sohn J, Alekseyenko AV, Leung JM, Cho I, et al. Altering the intestinal microbiota during a critical developmental window has lasting metabolic consequences. Cell (2014) 158:705-21. doi:10.1016/j. cell.2014.05.052

70. Nobel YR, Cox LM, Kirigin FF, Bokulich NA, Yamanishi S, Teitler I, et al. Metabolic and metagenomic outcomes from early-life pulsed antibiotic treatment. Nat Commun (2015) 6:7486. doi:10.1038/ncomms8486

71. Mackie RI, Sghir A, Gaskins HR. Developmental microbial ecology of the neonatal gastrointestinal tract. Am J Clin Nutr (1999) 69:1035S-45S.

72. Brunser Ó, Cruchet S, Gotteland M. Fisiología Gastrointestinal y Nutrición. Chile: Nestlé (2013). 331 p. Available from: https://www.nutrigroup.cl/ libro_fisiologia/libro_fisiologia_gastrointestinal.pdf

73. Yatsunenko T, Rey FE, Manary MJ, Trehan I, Dominguez-Bello MG, Contreras $\mathrm{M}$, et al. Human gut microbiome viewed across age and geography. Nature (2012) 486:222-7. doi:10.1038/nature11053

74. Avershina E, Lundgård K, Sekelja M, Dotterud C, Storrø O, Øien T, et al. Transition from infant- to adult-like gut microbiota. Environ Microbiol (2016) 18:2226-36. doi:10.1111/1462-2920.13248

75. Magne F, O'Ryan ML, Vidal R, Farfan M. The human gut microbiome of Latin America populations: a landscape to be discovered. Curr Opin Infect Dis (2016) 29(5):528-37. doi:10.1097/QCO.0000000000000300

76. Isolauri E. Development of healthy gut microbiota early in life. J Paediatr Child Health (2012) 48(Suppl 3):1-6. doi:10.1111/j.1440-1754.2012.02489.x

77. Dominguez-Bello MG, Costello EK, Contreras M, Magris M, Hidalgo G, Fierer N, et al. Delivery mode shapes the acquisition and structure of the initial microbiota across multiple body habitats in newborns. Proc Natl Acad Sci U S A (2010) 107:11971-5. doi:10.1073/pnas.1002601107

78. Khodayar-Pardo P, Mira-Pascual L, Collado MC, Martínez-Costa C. Impact of lactation stage, gestational age and mode of delivery on breast milk microbiota. J Perinatol (2014) 34:599-605. doi:10.1038/jp.2014.47

79. Cabrera-Rubio R, Mira-Pascual L, Mira A, Collado MC. Impact of mode of delivery on the milk microbiota composition of healthy women. J Dev Orig Health Dis (2016) 7:54-60. doi:10.1017/S2040174415001397

80. Grönlund MM, Lehtonen OP, Eerola E, Kero P. Fecal microflora in healthy infants born by different methods of delivery: permanent changes in intestinal flora after cesarean delivery. J Pediatr Gastroenterol Nutr (1999) 28:19-25. doi:10.1097/00005176-199901000-00007

81. Salminen S. Influence of mode of delivery on gut microbiota composition in seven year old children. Gut (2004) 53:1388-9. doi:10.1136/gut.2004.041640

82. Jakobsson HE, Abrahamsson TR, Jenmalm MC, Harris K, Quince C, Jernberg C, et al. Decreased gut microbiota diversity, delayed Bacteroidetes colonisation and reduced Th1 responses in infants delivered by caesarean section. Gut (2013) 63:559-66. doi:10.1136/gutjnl-2012-303249

83. Kabeerdoss J, Ferdous S, Balamurugan R, Mechenro J, Vidya R, Santhanam S, et al. Development of the gut microbiota in southern Indian infants from birth to 6 months: a molecular analysis. J Nutr Sci (2013) 2:e18. doi:10.1017/ jns.2013.6

84. Lee E, Kim B-J, Kang M-J, Choi KY, Cho H-J, Kim Y, et al. Dynamics of gut microbiota according to the delivery mode in healthy Korean infants. Allergy Asthma Immunol Res (2016) 8:471. doi:10.4168/aair.2016.8.5.471

85. Brumbaugh DE, Arruda J, Robbins K, Ir D, Santorico SA, Robertson CE, et al. Mode of delivery determines neonatal pharyngeal bacterial composition and 
early intestinal colonization. J Pediatr Gastroenterol Nutr (2016) 63:320-8. doi:10.1097/MPG.0000000000001124

86. Azad MB, Konya T, Maughan H, Guttman DS, Field CJ, Chari RS, et al. Gut microbiota of healthy Canadian infants: profiles by mode of delivery and infant diet at 4 months. Can Med Assoc J (2013) 185:385-94. doi:10.1503/ cmaj. 121189

87. Carding S, Verbeke K, Vipond DT, Corfe BM, Owen LJ. Dysbiosis of the gut microbiota in disease. Microb Ecol Health Dis (2015) 26:26191. doi:10.3402/ mehd.v26.26191

88. Björkstén B, Sepp E, Julge K, Voor T, Mikelsaar M. Allergy development and the intestinal microflora during the first year of life. J Allergy ClinImmunol (2001) 108:516-20. doi:10.1067/mai.2001.118130

89. Kalliomäki M, Kirjavainen P, Eerola E, Kero P, Salminen S, Isolauri E. Distinct patterns of neonatal gut microflora in infants in whom atopy was and was not developing. J Allergy ClinImmunol (2001) 107:129-34. doi:10.1067/ mai.2001.111237

90. Sjögren YM, Jenmalm MC, Böttcher MF, Björkstén B, Sverremark-Ekström E. Altered early infant gut microbiota in children developing allergy up to 5 years of age. Clin Exp Allergy (2009) 39:518-26. doi:10.1111/j.1365-2222. 2008.03156.x

91. Johansson MA, Sjögren YM, Persson J-O, Nilsson C, Sverremark-Ekström E. Early colonization with a group of lactobacilli decreases the risk for allergy at five years of age despite allergic heredity. PLoS One (2011) 6:e23031. doi:10.1371/journal.pone.0023031

92. Yap GC, Loo EX, Aw M, Lu Q, Shek LP, Lee BW. Molecular analysis of infant fecal microbiota in an Asian at-risk cohort-correlates with infant and childhood eczema. BMC Res Notes (2014) 7:166. doi:10.1186/17560500-7-166

93. Abrahamsson TR, Jakobsson HE, Andersson AF, Björkstén B, Engstrand L, Jenmalm MC. Low diversity of the gut microbiota in infants with atopic eczema. J Allergy ClinImmunol (2012) 129:434-40.e2. doi:10.1016/j.jaci. 2011.10.025

94. Rodríguez JM, Murphy K, Stanton C, Ross RP, Kober OI, Juge N, et al. The composition of the gut microbiota throughout life, with an emphasis on early life. Microb Ecol Health Dis (2015) 26:26050. doi:10.3402/mehd. v26.26050

95. Abrahamsson TR, Jakobsson HE, Andersson AF, Björkstén B, Engstrand L, Jenmalm MC. Low gut microbiota diversity in early infancy precedes asthma at school age. Clin Exp Allergy (2014) 44:842-50. doi:10.1111/cea.12253

96. van Nimwegen FA, Penders J, Stobberingh EE, Postma DS, Koppelman GH, Kerkhof M, et al. Mode and place of delivery, gastrointestinal microbiota, and their influence on asthma and atopy. JAllergy ClinImmunol (2011) 128:948-55.e3. doi:10.1016/j.jaci.2011.07.027

97. Wang M, Karlsson C, Olsson C, Adlerberth I, Wold AE, Strachan DP, et al. Reduced diversity in the early fecal microbiota of infants with atopic eczema. J Allergy ClinImmunol (2008) 121:129-34. doi:10.1016/j.jaci.2007.09.011

98. Forno E, Onderdonk AB, McCracken J, Litonjua AA, Laskey D, Delaney ML, et al. Diversity of the gut microbiota and eczema in early life. Clin Mol Allergy (2008) 6:11. doi:10.1186/1476-7961-6-11

99. Ismail IH, Oppedisano F, Joseph SJ, Boyle RJ, Licciardi PV, RobinsBrowne RM, et al. Reduced gut microbial diversity in early life is associated with later development of eczema but not atopy in high-risk infants. Pediatr Allergy Immunol (2012) 23:674-81. doi:10.1111/j.1399-3038.2012.01328.x

100. Penders J, Thijs C, van den Brandt PA, Kummeling I, Snijders B, Stelma F, et al. Gut microbiota composition and development of atopic manifestations in infancy: the KOALA Birth Cohort Study. Gut (2007) 56:661-7. doi:10.1136/gut.2006.100164

101. Kalliomäki M, Collado MC, Salminen S, Isolauri E. Early differences in fecal microbiota composition in children may predict overweight. Am J Clin Nutr (2008) 87:534-8.
102. Lutgendorff F, Akkermans LMA, Söderholm JD. The role of microbiota and probiotics in stress-induced gastro-intestinal damage. Curr Mol Med (2008) 8:282-98. doi:10.2174/156652408784533779

103. López-Boado YS, Wilson CL, Hooper LV, Gordon JI, Hultgren SJ, Parks WC. Bacterial exposure induces and activates matrilysin in mucosal epithelial cells. J Cell Biol (2000) 148:1305-15. doi:10.1083/jcb.148.6.1305

104. Rhee K-J, Sethupathi P, Driks A, Lanning DK, Knight KL. Role of commensal bacteria in development of gut-associated lymphoid tissues and preimmune antibody repertoire. J Immunol (2004) 172:1118-24. doi:10.4049/jimmunol. 172.2.1118

105. He B, Xu W, Santini PA, Polydorides AD, Chiu A, Estrella J, et al. Intestinal bacteria trigger $\mathrm{T}$ cell-independent immunoglobulin $\mathrm{A} 2$ class switching by inducing epithelial-cell secretion of the cytokine APRIL. Immunity (2007) 26:812-26. doi:10.1016/j.immuni.2007.04.014

106. Mazmanian SK, Round JL, Kasper DL. A microbial symbiosis factor prevents intestinal inflammatory disease. Nature (2008) 453:620-5. doi:10.1038/ nature 07008

107. Hansen CH, Andersen LS, Krych L, Metzdorff SB, Hasselby JP, Skov S, et al. Mode of delivery shapes gut colonization pattern and modulates regulatory immunity in mice. J Immunol (2014) 193:1213-22. doi:10.4049/jimmunol. 1400085

108. Dominguez-Bello MG, De Jesus-Laboy KM, Shen N, Cox LM, Amir A, Gonzalez A, et al. Partial restoration of the microbiota of cesarean-born infants via vaginal microbial transfer. Nat Med (2016) 22:250-3. doi:10.1038/ nm.4039

109. Garcia Rodenas CL, Lepage M, Ngom-Bru C, Fotiou A, Papagaroufalis K, Berger B. Effect of formula containing Lactobacillus reuteri DSM 17938 on fecal microbiota of infants born by cesarean-section. J Pediatr Gastroenterol Nutr (2016) 63:681-7. doi:10.1097/MPG.0000000000001198

110. Ryding EL, Lukasse M, Kristjansdottir H, Steingrimsdottir T, Schei B; Bidens Study Group. Pregnant women's preference for cesarean section and subsequent mode of birth - a six-country cohort study. J Psychosom Obstet Gynaecol (2016) 37:75-83. doi:10.1080/0167482X.2016.1181055

111. Hauck YL, Stoll KH, Hall WA, Downie J. Association between childbirth attitudes and fear on birth preferences of a future generation of Australian parents. Women Birth (2016) 29:511-7. doi:10.1016/j.wombi.2016. 05.001

112. Mazzoni A, Althabe F, Gutierrez L, Gibbons L, Liu NH, Bonotti AM, et al. Women's preferences and mode of delivery in public and private hospitals: a prospective cohort study. BMC Pregnancy Childbirth (2016) 16:34. doi:10.1186/s12884-016-0824-0

113. Sandall J, Soltani H, Gates S, Shennan A, Devane D. Midwife-led continuity models versus other models of care for childbearing women. In: Sandall J, editor. Cochrane Database of Systematic Reviews. Chichester, UK: John Wiley \& Sons, Ltd (2016). doi:10.1002/14651858.CD004667.pub5

114. Ji H, Jiang H, Yang L, Qian X, Tang S. Factors contributing to the rapid rise of caesarean section: a prospective study of primiparous Chinese women in Shanghai. BMJOpen (2015) 5:e008994. doi:10.1136/bmjopen-2015008994

Conflict of Interest Statement: The authors declare that the research was conducted in the absence of any commercial or financial relationships that could be construed as a potential conflict of interest.

Copyright $\odot 2017$ Magne, Puchi Silva, Carvajal and Gotteland. This is an open-access article distributed under the terms of the Creative Commons Attribution License (CC BY). The use, distribution or reproduction in other forums is permitted, provided the original author(s) or licensor are credited and that the original publication in this journal is cited, in accordance with accepted academic practice. No use, distribution or reproduction is permitted which does not comply with these terms. 